\title{
Thy-1 stimulation of mouse $T$ cells induces a delayed $T$ cell receptor-like signal that results in $\mathrm{Ca}^{2+}$-independent cytotoxicity
}

\author{
SUZANNE FURLONG ${ }^{1}$, MELANIE R. POWER COOMBS ${ }^{2}$ and DAVID W. HOSKIN ${ }^{1-3}$ \\ Departments of ${ }^{1}$ Microbiology and Immunology, ${ }^{2}$ Pathology and ${ }^{3}$ Surgery, \\ Dalhousie University, Halifax, NS B3H 4R2, Canada
}

Received February 17, 2017; Accepted June 26, 2017

DOI: $10.3892 / \mathrm{mmr} .2017 .7242$

\begin{abstract}
Antibody-mediated crosslinking of Thy-1 [also known as cluster of differentiation (CD)90], results in a T cell receptor (TcR)-like signal; however, the impact of Thy-1 stimulation in comparison to TcR stimulation on T cell activation and effector function has yet to be fully elucidated. In the present study, the outcome of Thy-1- and TcR-induced stimulation of $\mathrm{T}$ cells was investigated in mice, using fragment crystalizable $(\mathrm{Fc})$ receptor-bound antibodies and costimulatory signals provided by syngeneic lipopolysaccharide-matured bone marrow-derived dendritic cells. Compared with TcR signaling, Thy-1 signaling initiated a less robust proliferative response in $\mathrm{T}$ cells, as determined by tritiated-thymidine incorporation. In addition, enzyme-linked immunosorbent assays revealed that interleukin-2 production was reduced, and the expression of CD25 and cyclin D3 was weaker in Thy-1-stimulated cells, as determined by western blotting; however, the expression of cyclin-dependent kinase 6 was similar to that in TcR-induced $\mathrm{T}$ cells. Furthermore, western blotting demonstrated that the phosphorylation of $\zeta$-chain-associated protein kinase 70 and extracellular signal-regulated kinase 1/2 was delayed following Thy-1 stimulation. DNA fragmentation assays revealed that cytotoxic effector function was also slower to develop in Thy-1-stimulated $\mathrm{T}$ cells, required more time to be effective and was largely $\mathrm{Ca}^{2+}$-independent; these findings suggested that Fas ligand rather than granule-associated perforin was involved in T cell effector function. In conclusion, the present results suggested that Thy-1 signaling may contribute to the regulation of $\mathrm{T}$ cell homeostasis and the development of non-specific T cell-mediated cytotoxicity. However, further studies are required to elucidate the exact physiological roles of TcR-like signals that result from Thy-1 crosslinking and to investigate the molecular mechanisms that are involved.
\end{abstract}

Correspondence to: Professor David W. Hoskin, Department of Microbiology and Immunology, Dalhousie University, 5850 College Street, Halifax, NS B3H 4R2, Canada

E-mail: dwhoskin@dal.ca

Key words: cytotoxicity, proliferation, signal transduction, Thy-1, T lymphocyte

\section{Introduction}

Thy-1 [also known as cluster of differentiation (CD)90] is a $25 \mathrm{kDa}$ glycosylphosphatidylinositol (GPI)-anchored cell surface protein that is involved in numerous biological processes, including $\mathrm{T}$ cell activation and apoptosis, wound healing and tumor suppression (1-3). Thy-1 is abundantly expressed on mouse thymocytes and peripheral $\mathrm{T}$ cells (4); however, the exact roles of Thy-1 in mouse $\mathrm{T}$ cell function have yet to be elucidated (1-3). Paradoxically, Thy-1 signaling has been reported to exert stimulatory and suppressive effects on murine T cells; for example, thymocytes from Thy-1-deficient mice appeared to be hyper-responsive to $\mathrm{T}$ cell receptor (TcR) stimulation (4), which suggested that Thy-1 may inhibit TcR signaling under certain circumstances. In addition, CD4 ${ }^{+}$ mouse $\mathrm{T}$ cells that were stimulated by Thy- 1 in the absence of costimulatory signals acquired a $\mathrm{T}$ regulatory cell-like phenotype (5), which suggested a role for Thy-1 in the maintenance of $\mathrm{T}$ cell homeostasis. Conversely, TcR-driven proliferation of peripheral $\mathrm{T}$ cells was suppressed in Thy-1-deficient mice (6), whereas Thy-1 inhibition interfered with the induction of non-specific cytotoxic T cells mediated by anti-CD3 monoclonal antibodies (7). These data suggested that Thy-1 may potentiate TcR signaling, possibly through enhanced phosphorylation of the raft-associated adaptor protein linker for activation of T cells (8). In addition, the activation of Thy- 1 in the presence of costimulatory signals provided by syngeneic dendritic cells was previously reported to result in T cell proliferation, interleukin (IL)-2 production and high-affinity IL-2 receptor subunit $\alpha$ (also known as CD25) expression (7), consistent with the role of Thy-1 in providing a non-specific TcR-like stimulatory signal. Similar to TcR signaling, Thy-1 stimulation of $\mathrm{T}$ cells in the context of costimulation by dendritic cells promotes the expression of cytotoxic effector molecules, including perforin, granzyme B and Fas ligand; however, unlike TcR signaling, Thy-1 stimulation did not induce detectable cytotoxicity in a $4 \mathrm{~h}$ redirected lysis assay (7).

The molecular mechanism by which GPI-anchored proteins such as Thy-1, which lack cytoplasmic domains, transmit signals to the $\mathrm{T}$ cell nucleus from the extracellular environment is yet to be elucidated. Thy- 1 crosslinking has previously been reported to activate a TcR-like signal transduction pathway that involves intracellular $\mathrm{Ca}^{2+}$ flux (9), and the activation of signaling molecules, including protein tyrosine 
kinases, calcineurin, phospholipase $\mathrm{C} \gamma$, protein kinase $\mathrm{C}$, phosphatidylinositol-4,5-bisphosphate 3-kinase (PI3K), and mitogen-activated protein kinases (MAPKs) $(10,11)$ Thy-1-induced $\mathrm{T}$ cell activation was demonstrated to require the coexpression of the TcR/CD3 complex (12), which indicated a potential role for TcR-associated signal transduction pathways in Thy-1 signaling. However, Thy-1 stimulation was previously demonstrated to induce $\mathrm{Ca}^{2+}$ flux and other signaling events in Thy-1-transfected B cells that lack TcR (9), which indicated the association of highly conserved signaling molecules with Thy-1. Notably, Thy-1 is able to interact, via phosphorylated (p)-p85-90, with the protein tyrosine kinases Fyn and lymphocyte-specific protein tyrosine kinase (Lck), PI3K, C-terminal Src kinase, the GTPase-activating protein Ras, Vav and the tyrosine phosphatase CD45 (13-16). As Thy-1 co-localizes with protein tyrosine kinases and other signaling molecules, it may be hypothesized that antibody-mediated crosslinking of Thy-1, within plasma membrane microdomains, may lead to $\mathrm{T}$ cell activation by promoting lipid raft aggregation, similar to the mechanisms previously reported for other GPI-anchored proteins that are expressed by lymphocytes and hematopoietic cells (17).

Functional outcomes of the activation of cell-surface receptors and their associated signal-transduction pathways are dictated by signal strength and kinetics. For example, the decision between $\mathrm{CD}^{+}$and $\mathrm{CD} 8^{+}$lineage commitment during thymocyte development depends on the strength and duration of intracellular $\mathrm{Ca}^{2+}$ flux and extracellular signal-regulated kinase (ERK)-mediated signaling induced by TcR activation (18). The strength of the TcR signal also influences the development of various $\mathrm{T}$ helper cell subsets $(19,20)$, the expression of homing receptors that guide $\mathrm{T}$ cell migration (21), and the effector function of cytotoxic T lymphocytes $(22,23)$. However, the consequences of $\mathrm{T}$ cell activation by Thy- 1 have yet to be fully elucidated. Therefore, the aim of the present study was to investigate the effects of Thy-1 stimulation, in the context of costimulation provided by syngeneic bone marrow-derived dendritic cells (BMDCs), on the activation and subsequent effector function of $\mathrm{T}$ cells, compared with TcR crosslinking.

\section{Materials and methods}

Animals. A total of 90 female C57BL/6 mice (age, 6-8 weeks; weight, 20-24 g) were purchased from Charles River Laboratories, Inc. (Wilmington, MA, USA) and housed at $21^{\circ} \mathrm{C}$ and $50 \%$ humidity with a 12-h light/dark cycle in the Carleton Animal Care Facility at Dalhousie University (Halifax, Canada). Mice were maintained on standard rodent chow and water, which was supplied ad libitum. Animal protocols were consistent with the guidelines of the Canadian Council on Animal Care (www.ccac.ca) and were approved by the Dalhousie University Committee on Laboratory Animals.

Cell lines. Mouse P815 mastocytoma cells were obtained from American Type Culture Collection (ATCC; Manassas, VA, USA). Cells were cultured in RPMI-1640 medium (Sigma-Aldrich; Merck KGaA, Darmstadt, Germany) supplemented with $5 \%$ heat-inactivated fetal calf serum (FCS), $100 \mathrm{U} / \mathrm{ml}$ penicillin, $100 \mu \mathrm{g} / \mathrm{ml}$ streptomycin, $2 \mathrm{mM}$ L-glutamine and 5 mM 4-(2-hydroxyethyl)-1-piperazineethanesulfonic acid
(HEPES) buffer (all purchased from Invitrogen; Thermo Fisher Scientific, Inc., Waltham, MA, USA), and maintained at $37^{\circ} \mathrm{C}$ in a humidified $5 \% \mathrm{CO}_{2}$ atmosphere.

Cytokines and antibodies. Recombinant mouse granulocyte-macrophage colony-stimulating factor (GM-CSF) and IL-2 were purchased from R\&D Systems, Inc. (Minneapolis, MN, USA). Functional grade (FG) purified rat anti-Thy-1 immunoglobulin (Ig)G2c (clone G7, cat. no. 553015) monoclonal antibody (mAb) and FG purified rat $\mathrm{IgG} 2 \mathrm{c}$ isotype control (cat. no. 553981) were purchased from BD Biosciences (Franklin Lakes, NJ, USA). FG purified hamster anti-TcR $\beta$ IgG mAb (clone H57-597, cat. no. 5013368), FG purified hamster IgG isotype control (cat. no. 16-4888-81), fluorescein isothiocyanate (FITC)-conjugated hamster anti-CD3e IgG mAb (clone 145-2C11, cat. no. 11-0031-82), FITC-conjugated hamster anti-CD11c IgG mAb (clone N418, cat. no. 11-0114-82), FITC-conjugated hamster anti-CD80 IgG mAb (clone 16-10A1, cat. no. 17-0801-82), FITC-conjugated rat anti-CD86 IgG2a mAb (clone GL1, cat. no. 11-0862-82), FITC-conjugated rat anti-MHC Class II (I-A/I-E) IgG2b mAb (clone M5/114.15.2, cat. no. 11-5321-82), and FITC-conjugated rat IgG1 (cat. no. 11-4812-82) were purchased from eBioscience (Thermo Fisher Scientific, Inc.). FITC-conjugated rat anti-CD25 IgG1 (clone PC61.5.3, cat. no. CL8925F) was purchased from Cedarlane Laboratories (Burlington, ON, Canada). Anti-survivin (clone 71G4B7, rabbit IgG, cat.no. 2808), anti-cyclin-dependent kinase 6 (CDK6) (clone DCS83, mouse IgG1, cat. no. 3136S), anti-cyclin D3 (clone DCS22, mouse IgG1, cat. no. 2936S), anti- $\zeta$-chain-associated protein kinase (ZAP)-70 (clone 99F2, rabbit IgG, cat. no. 2705S) and anti-p-ZAP-70 (Tyr319, polyclonal rabbit IgG, cat. no. 2701S) primary antibodies were purchased from Cell Signaling Technology, Inc. (Danvers, MA, USA). Anti- $\beta$-actin (polyclonal goat IgG, cat. no. sc-1616), anti-p-ERK1/2 (clone E-4, mouse IgG2a, cat. no. sc-7383), anti-ERK1/2 (polyclonal rabbit IgG, cat. no. sc-153), anti-CD25 (polyclonal rabbit IgG, cat. no. sc-666) primary antibodies, and the secondary antibodies horseradish peroxidase (HRP)-conjugated bovine anti-goat IgG (cat. no. sc-2378), HRP-conjugated donkey anti-rabbit IgG (cat. no. sc-2313), and HRP-conjugated goat anti-mouse IgG (cat. no. sc-2005) were obtained from Santa Cruz Biotechnology, Inc. (Dallas, TX, USA).

$T$ cell isolation. Mice were sacrificed, spleens were removed and a single cell suspension was prepared in phosphate-buffered saline (PBS, pH 7.2) at $4^{\circ} \mathrm{C}$ using a hand-held tissue homogenizer. Erythrocytes were depleted by hypotonic shock. Briefly, spleen cells were resuspended at room temperature in sterile $0.2 \%$ saline followed by an equal volume of sterile $1.6 \%$ saline following $20 \mathrm{sec}$. Magnetic-activated cell sorting was used for $\mathrm{CD}^{+} \mathrm{T}$ cell isolation by negative selection with the Pan T Cell Isolation MACS kit (Miltenyi Biotec, Inc., San Diego, CA, USA), according to the manufacturer's instructions. Isolated $\mathrm{T}$ cells were $>98 \%$ pure, as determined by assessing CD3 expression using flow cytometry, as described in the following Flow cytometry subsection.

BMDC generation. BMDCs were obtained as previously described with slight modifications (24). Briefly, C57BL/6 
mice were sacrificed and bone marrow was flushed from the tibiae and femurs with PBS under aseptic conditions. Erythrocytes were depleted from the bone marrow preparations by hypotonic shock, as aforementioned. Bone marrow cells $\left(1 \times 10^{6}\right.$ cells/well) were resuspended and cultured at $37^{\circ} \mathrm{C}$ in a humidified $5 \% \mathrm{CO}_{2}$ atmosphere in 6-well tissue culture plates (Sarstedt AG \& Co., Nümbrecht, Germany) containing BMDC medium (RPMI-1640 medium supplemented with $10 \%$ heat-inactivated FCS, $2 \mathrm{mM}$ L-glutamine, $200 \mathrm{U} / \mathrm{ml}$ penicillin, $200 \mu \mathrm{g} / \mathrm{ml}$ streptomycin, $5 \mathrm{mM}$ HEPES buffer, $50 \mu \mathrm{M}$ $\beta$-mercaptoethanol and $20 \mathrm{ng} / \mathrm{ml}$ GM-CSF). The medium was replaced every 3 days. On day 8 , non-adherent cells were collected using a pipette and transferred to new culture plates with fresh BMDC medium. BMDCs were matured by culture at $37^{\circ} \mathrm{C}$ in a humidified $5 \% \mathrm{CO}_{2}$ atmosphere in the presence of $1 \mu \mathrm{g} / \mathrm{ml}$ lipopolysaccharide (LPS; Sigma-Aldrich; Merck $\mathrm{KGaA}$ ) on day 8 or 9 , and then harvested with a cell scraper following $24 \mathrm{~h}$ for use in experiments on day 9 or 10, respectively. BMDCs were determined to by $>80 \%$ pure by assessing CD11c, major histocompatibility complex class II, CD80 and CD86 expression using flow cytometry, as described in the following Flow cytometry subsection.

$T$ cell activation. $\mathrm{T}$ cells $\left(2.5 \times 10^{4}\right.$ cells/well $)$ were seeded in 96-well round-bottom plates (Sarstedt AG \& Co.) and activated with or without LPS-matured syngeneic BMDCs (8,000 cells/well), with anti-Thy- $1 \mathrm{mAb}$, anti-TcR $\beta \mathrm{mAb}$ or the appropriate isotype control at a final concentration of $6 \mu \mathrm{g} / \mathrm{ml}$ (1:167 dilution, unless otherwise specified), by culture at $37^{\circ} \mathrm{C}$ in a humidified $5 \% \mathrm{CO}_{2}$ atmosphere for 24, 48, 72 and/or $96 \mathrm{~h}$, depending on the nature of the experiment. This ratio of $\mathrm{T}$ cells to BMDCs has been reported to promote optimal anti-Thy-1 mAb-mediated T cell proliferation, following Thy-1 crosslinking by fragment crystalizable $(\mathrm{Fc})$ receptor-bound $\mathrm{Ab}$ together with costimulatory signaling (25). For flow cytometry, western blotting, IL-2 measurements and cytotoxicity assays, T cells $\left(1.25-2.5 \times 10^{6}\right.$ cells/well) were seeded in 24-well flat-bottom plates (Sarstedt AG \& Co.) and activated with or without LPS-matured syngeneic BMDCs (4-8x10 4 cells/well) and anti-Thy- $1 \mathrm{mAb}$, anti-TcR $\beta \mathrm{mAb}$, or the appropriate isotype control, at a final concentration of $6 \mu \mathrm{g} / \mathrm{ml}$ (1:167 dilution), then cultured at $37^{\circ} \mathrm{C}$ in a humidified $5 \% \mathrm{CO}_{2}$ atmosphere for $5,10,60,120,240$ and/or $480 \mathrm{~min}$, or 12, 24, 48 and/or $72 \mathrm{~h}$, depending on the nature of the experiment. T cells were cultured in RPMI-1640 medium (Sigma-Aldrich; Merck $\mathrm{KGaA}$ ) supplemented with 5\% heat-inactivated FCS, $100 \mathrm{U} / \mathrm{ml}$ penicillin, $100 \mu \mathrm{g} / \mathrm{ml}$ streptomycin, $2 \mathrm{mM}$ L-glutamine and $5 \mathrm{mM}$ HEPES buffer, and maintained at $37^{\circ} \mathrm{C}$ in a humidified $5 \% \mathrm{CO}_{2}$ atmosphere.

$T$ cell proliferation assay. T cells $\left(2.5 \times 10^{4}\right.$ cells/well $)$ were plated in 96-well round-bottomed plates and cultured in the presence of anti-Thy- $1 \mathrm{mAb}$, anti-TcR $\beta \mathrm{mAb}$ or the appropriate isotype control as aforementioned for 24-96 h. They were pulsed with $0.25 \mu \mathrm{Ci}$ of tritiated thymidine $\left(\left[{ }^{3} \mathrm{H}\right]-\mathrm{TdR}\right.$; MP Biomedicals LLC, Santa Ana, CA, USA) during the final $6 \mathrm{~h}$ of culture. To determine whether exogenous IL-2 would induce $\mathrm{T}$ cell proliferation in response to Thy-1 stimulation, anti-Thy-1 mAb was combined with $100 \mathrm{U} / \mathrm{ml}$ recombinant mouse IL-2 or the vehicle. $\left[{ }^{3} \mathrm{H}\right]-\mathrm{TdR}$-labeled DNA was harvested onto glass fiber filter mats using a Titertek Cell Harvester (Skatron, Sterling, VA, USA), then radioactivity was determined using a Beckman LS6000IC liquid scintillation counter (Beckman Coulter, Inc., Brea, CA, USA). Data were analyzed using Microsoft Office Excel's Analysis ToolPak (Microsoft Corporation, Redmond, WA, USA).

Western blot analysis. Cells $\left(1.25 \times 10^{6}\right.$ cells $\left./ \mathrm{ml}\right)$ were washed once with ice-cold PBS, centrifuged at $500 \mathrm{x} \mathrm{g}$ for $5 \mathrm{~min}$ at $4{ }^{\circ} \mathrm{C}$, and then lysed with ice-cold lysis buffer $[50 \mathrm{mM}$ Tris- $\mathrm{HCl}$ (pH 7.5), $150 \mathrm{mM} \mathrm{NaCl}, 50 \mathrm{mM} \mathrm{Na} \mathrm{HPO}_{4}, 0.25 \%$ sodium deoxycholate (w/v), 0.1\% Nonidet P-40 (v/v), 5 mM EDTA and $5 \mathrm{mM}$ EGTA], supplemented with fresh protease and phosphatase inhibitors $\left(100 \mu \mathrm{M} \mathrm{Na}_{3} \mathrm{VO}_{4}, 10 \mathrm{mM} \mathrm{NaF}\right.$, $1 \mathrm{mM}$ phenylmethylsulfonyl fluoride, $10 \mu \mathrm{g} / \mathrm{ml}$ aprotinin, $10 \mu \mathrm{M}$ phenylarsine oxide, $1 \mathrm{mM}$ dithiothreitol, $5 \mu \mathrm{g} / \mathrm{ml}$ leupeptin and $5 \mu \mathrm{g} / \mathrm{ml}$ pepstatin) for $30 \mathrm{~min}$ on ice. Cellular debris was removed from the lysates by centrifugation at $10,000 \mathrm{x} \mathrm{g}$ for $10 \mathrm{~min}$ at $4^{\circ} \mathrm{C}$. Total protein concentration in the lysates was determined using a Bradford Assay kit (Bio-Rad Laboratories, Inc., Hercules, CA, USA). Samples were diluted with SDS-PAGE sample buffer [containing $200 \mathrm{mM}$ Tris-HCl (pH 6.8), 30\% glycerol (v/v), 6\% SDS $(\mathrm{w} / \mathrm{v}), 15 \% \beta$-mercaptoethanol (v/v) and $0.01 \%$ bromophenol blue $(\mathrm{w} / \mathrm{v})]$. Lysates were heated at $90-100^{\circ} \mathrm{C}$ for $5 \mathrm{~min}$ to promote denaturation and stored at $-80^{\circ} \mathrm{C}$ until used. Equal amounts of extracted protein samples (10-20 $\mu \mathrm{g})$ were separated on Tris- $\mathrm{HCl}$ acrylamide resolving gels and transferred onto nitrocellulose membranes using the iBlot Dry Blotting system (Invitrogen; Thermo Fisher Scientific, Inc.). Membranes were washed once in TBS containing $0.05 \%$ Tween-20 (TBST), and blocked in TBST containing $5 \%$ fat-free milk powder (w/v) for $1 \mathrm{~h}$ at room temperature or overnight at $4^{\circ} \mathrm{C}$ with gentle agitation. Membranes were washed 3 times with TBST and incubated with the primary antibodies (anti- $\beta$-actin, anti-CD25, anti-CDK6, anti-cyclin D3, anti-ERK1/2, anti-p-ERK1/2, anti-survivin, anti-ZAP-70, or anti-p-ZAP-70 mAb), all at a 1:500 working dilution in TBST containing $5 \%$ fat-free milk powder $(\mathrm{w} / \mathrm{v})$, for $1 \mathrm{~h}$ at room temperature or overnight at $4^{\circ} \mathrm{C}$ with gentle agitation. Membranes were washed with TBST and then incubated with the HRP-conjugated secondary polyclonal antibodies (bovine anti-goat IgG for anti- $\beta$-actin; donkey anti-rabbit IgG for anti-CD25, anti-ERK1/2, anti-survivin, anti-ZAP-70 and anti-p-ZAP-70; goat anti-mouse for anti-CDK6, anti-cyclin D3 and anti-p-ERK1/2), all at a 1:1,000 working dilution in TBST containing $5 \%$ fat-free milk powder $(\mathrm{w} / \mathrm{v})$, for $1 \mathrm{~h}$ at room temperature with gentle agitation. Membranes were washed with TBST and protein bands were visualized using enhanced chemiluminescence (ECL) or ECL Plus reagents (GE Healthcare Life Sciences, Little Chalfont, UK). Excess reagent was removed and membranes were exposed to $\mathrm{X}$-ray film in the dark; X-ray film was developed using a Kodak X-OMAT 1000A processor (Kodak, Rochester, NY, USA). ImageJ software (version 1.45; National Institutes of Health, Bethesda, MD, USA) was used for densitometric analysis. Protein expression was normalized to $\beta$-actin.

Flow cytometry. Cells $\left(1.25 \times 10^{6}\right.$ cells $\left./ \mathrm{ml}\right)$ were cultured for $48 \mathrm{~h}$ in the presence of $6 \mu \mathrm{g} / \mathrm{ml}$ anti-Thy- $1 \mathrm{mAb}$ or anti-TcR $\beta$ 
$\mathrm{mAb}$, as aforementioned. Cells were then washed in cold fluorescence-activated cell sorting (FACS) buffer containing $1 \%$ bovine serum albumin (w/v, Sigma-Aldrich; Merck KGaA) and $0.2 \%$ sodium azide (w/v) in PBS. Cells were then incubated with a 1:100 dilution of FITC-conjugated anti-CD25 mAb or the appropriate isotype control. Cells were incubated on ice in the dark for $45 \mathrm{~min}$, washed 3 times with cold FACS buffer and resuspended in fixative solution (1\% paraformaldehyde in PBS) at room temperature and immediately stored overnight in the dark at $4^{\circ} \mathrm{C}$ prior to analysis using a BD FACSCalibur flow cytometer with BD CellQuest software version 3.3 (BD Biosciences), and the resulting data were analyzed using FCS Express software version 3.0 (De Novo Software, Glendale, CA, USA).

Cytokine measurement. IL-2 expression levels in T cell culture supernatants were measured using an IL-2 enzyme-linked immunosorbent assay kit (ELISA, cat. no. 555148; BD Biosciences), according to the manufacturer's instructions. Absorbance was measured at $450 \mathrm{~nm}$ with a wavelength correction for $570 \mathrm{~nm}$ using an ELx800 microplate reader and KCjunior software version 1.17 (both from BioTek Instruments, Inc., Winooski, VT, USA). SoftMax Pro software version 4.3 (Molecular Devices, LLC, Sunnyvale, CA, USA) was used to determine cytokine concentrations from the absorbance readings.

$T$ cell-mediated cytotoxicity assay. A DNA fragmentation assay was used to measure cytotoxic effector function, as previously described (26). Briefly, P815 target cells $\left(5 \times 10^{6}\right)$, which are sensitive to anti-CD3 mAb-redirected lysis (7), were resuspended in $\left[{ }^{3} \mathrm{H}\right]-\mathrm{TdR}(5 \mu \mathrm{Ci} / \mathrm{ml})$ and radiolabeled by incubation for $4 \mathrm{~h}$ at $37^{\circ} \mathrm{C}$ in a humidified $5 \% \mathrm{CO}_{2}$ atmosphere, and subsequently washed and resuspended in RPMI-1640 medium supplemented with $5 \%$ heat-inactivated FCS, $100 \mathrm{U} / \mathrm{ml}$ penicillin, $100 \mu \mathrm{g} / \mathrm{ml}$ streptomycin, $2 \mathrm{mM}$ L-glutamine and $5 \mathrm{mM}$ HEPES buffer. P815 cells $\left(5 \times 10^{4}\right.$ cells/well) were added in quadruplicate to 96 -well round-bottom tissue culture plates and co-cultured at a ratio of 1:50 with resting $\mathrm{T}$ cells, $\mathrm{T}$ cells that had been activated with $6 \mu \mathrm{g} / \mathrm{ml}$ anti-Thy- $1 \mathrm{mAb}$ - or anti-TcR mAb for 4,18 , or $24 \mathrm{~h}$, or with LPS-matured B cells (negative control) for 4 or $24 \mathrm{~h}$ at $37^{\circ} \mathrm{C}$ in a humidified $5 \%$ $\mathrm{CO}_{2}$ atmosphere. To determine whether cytotoxicity was $\mathrm{Ca}^{2+}$-dependent or $\mathrm{Ca}^{2+}$-independent, radiolabeled P815 cells and $\mathrm{T}$ cells that had been activated with $6 \mu \mathrm{g} / \mathrm{ml}$ anti-Thy-1 $\mathrm{mAb}$ - or anti-TcR mAb for $24 \mathrm{~h}$ were combined at a ratio of 1:50 and incubated for 4 or $24 \mathrm{~h}$ with medium alone, vehicle (PBS), or $4 \mathrm{mM}$ EGTA and $2 \mathrm{mM} \mathrm{MgCl}_{2}$ to prevent $\mathrm{Ca}^{2+}$-dependent granule-mediated cytotoxicity (27). Radiolabeled DNA was harvested onto glass fiber filter mats using the Titertek Cell Harvester (Skatron) and radioactivity was then measured (counts/min; cpm) using liquid scintillation counting, as aforementioned. The percentage of DNA fragmentation of P815 target cells was calculated according to the following formula: DNA fragmentation $(\%)=1-\left[\left(\mathrm{C}_{\mathrm{cpm}}-\mathrm{E}_{\mathrm{cpm}}\right) / \mathrm{C}_{\mathrm{cpm}}\right]$, where $\mathrm{E}$ is intact DNA from P815 target cells co-cultured with effector cells and C is intact DNA from P815 target cells alone.

Statistical analysis. Data are expressed as either the mean \pm standard deviation or the mean \pm standard error of the mean of 3 independent experiments. The statistical significance of the differences between groups was determined using Student's t-test for pair-wise comparisons or one-way analysis of variance with a Bonferroni post hoc test for multiple comparisons (InStat v2.04a GraphPad Software; GraphPad Software, Inc., La Jolla, CA, USA). P<0.05 was considered to indicate a statistically significant difference.

\section{Results}

Induction of DNA synthesis is weaker following Thy-1 signaling compared with TcR signaling. DNA synthesis induced by Thy- 1 or $\mathrm{TcR} \beta \mathrm{mAb}$ crosslinking, in the presence of syngeneic BMDCs as a source of costimulation, was investigated using a $\left[{ }^{3} \mathrm{H}\right]-\mathrm{TdR}$ incorporation assay. Thy-1 stimulation appeared to be a less potent inducer of DNA synthesis compared with TcR $\beta$ stimulation at the various $\mathrm{mAb}$ concentrations tested (Fig. 1A), which indicated that the Thy-1-associated signal is weaker compared with the signal generated by $\mathrm{TcR} \beta$ crosslinking. Subsequent experiments used anti-Thy- $1 \mathrm{mAb}$ and anti-TcR $\beta$ $\mathrm{mAb}$ at a final concentration of $6 \mu \mathrm{g} / \mathrm{ml}$, as this was in excess of the concentration needed to achieve a maximum response. The kinetics of DNA synthesis induced by Thy- 1 and TcR $\beta$ crosslinking were similar, both reaching a peak following $72 \mathrm{~h}$ of culture despite Thy- 1 stimulation being weaker than TcR $\beta$ stimulation (Fig. 1B).

The effects of Thy- 1 and TcR signaling on T cell transition from the quiescent $G_{0}$ state into the $G_{1}$ phase of the cell cycle, which involves CDK4 and CDK6 activation by D-type cyclins (28), were also explored. The expression of cyclin D3, which activates CDK6, was significantly decreased in anti-Thy-1 mAb-stimulated $\mathrm{T}$ cells compared with in anti-TcR $\beta$ mAb-stimulated $\mathrm{T}$ cells at $48 \mathrm{~h}$, however, in both cases cyclin D3 expression peaked at 48 h (Fig. 2A). Notably, no significant differences were identified for the expression of CDK6 with either of the activating conditions; however, in both instances CDK6 expression peaked at 24-48 h (Fig. 2B). These findings suggested that an alternative pathway of CDK6 activation may be stimulated in anti-Thy- $1 \mathrm{mAb}$-induced $\mathrm{T}$ cells. In addition, the expression of the antiapoptotic protein survivin, as determined by western blot analysis, was also similar in $\mathrm{T}$ cells following Thy-1- and TcR $\beta$-mediated stimulation (data not shown).

Induction of CD25 and IL-2 production is weaker following Thy-1 stimulation compared with TcR $\beta$. Western blot analysis revealed that CD25 expression in T cells was significantly lower at 24 and $48 \mathrm{~h}$ following Thy-1 mAb crosslinking compared with TcR $\beta$ crosslinking in the presence of syngeneic BMDCs (Fig. 3). The detection of CD25 as multiple protein bands at $\sim 55 \mathrm{kDa}$ may possibly be attributed to heterogeneous post-translational modifications at multiple $\mathrm{N}$ - and O-glycosylation sites of the protein molecule (29). Similar results were obtained following the detection of cell-surface CD25 on anti-Thy-1- and anti-TcR $\beta$-stimulated $\mathrm{T}$ cells using flow cytometry. Following $48 \mathrm{~h}$ of culture, the mean fluorescence intensity (in channel fluorescence units) of cells stained with FITC-conjugated anti-CD25 mAb was $47 \pm 2$ for TcR stimulation, and $21 \pm 2$ for Thy- 1 stimulation $(\mathrm{P}<0.01$; data not presented). 


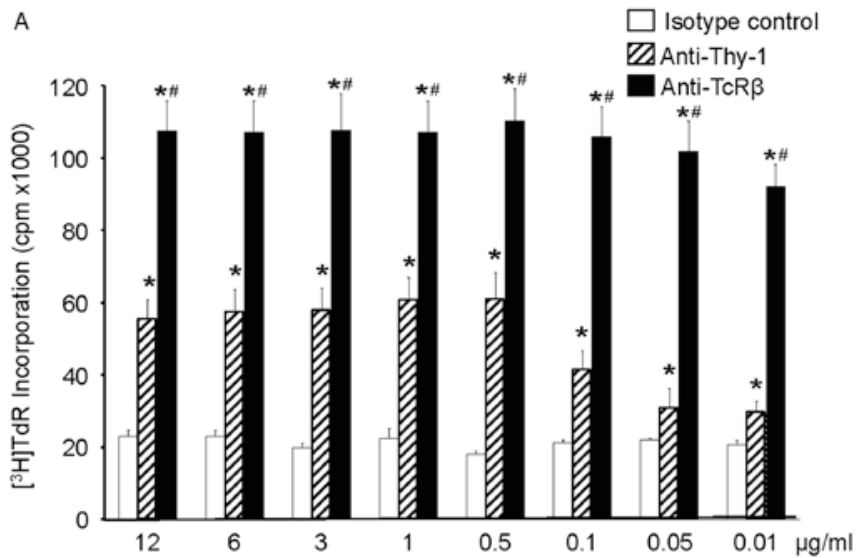

B

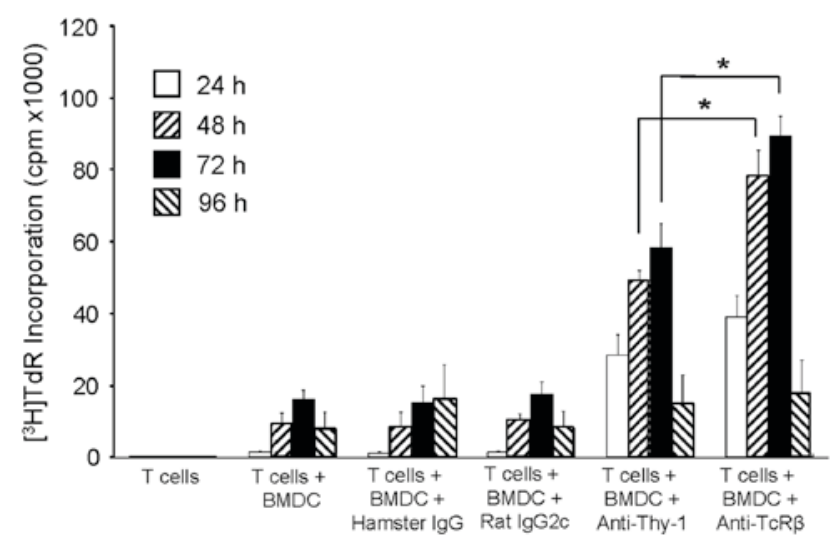

Figure 1. Thy-1 signaling induces a weak proliferative response in T cells compared with TcR signaling. Co-cultures of $\mathrm{T}$ cells and lipopolysaccharide-matured BMDCs were incubated in the presence of (A) the indicated concentrations of anti-Thy- $1 \mathrm{mAb}$, anti-TcR $\beta \mathrm{mAb}$ or an isotype control for $72 \mathrm{~h}$, or (B) $6 \mu \mathrm{g} / \mathrm{ml}$ of anti-Thy- $1 \mathrm{mAb}$, anti-TcR $\beta \mathrm{mAb}$ or the isotype control for the indicated times. Cultures were pulsed with $\left[{ }^{3} \mathrm{H}\right]-\mathrm{TdR}$ for $6 \mathrm{~h}$, cells were harvested and DNA synthesis was evaluated based on $\left[{ }^{3} \mathrm{H}\right]-\mathrm{TdR}$ incorporation. Data are expressed as the mean \pm standard error of the mean of 3 independent experiments. " $\mathrm{P}<0.05$ vs. control (or as indicated); ${ }^{"} \mathrm{P}<0.05$ vs. anti-Thy- 1 treatment. $\left[{ }^{3} \mathrm{H}\right]-\mathrm{TdR}$, tritiated thymidine; BMDC, bone marrow-derived dendritic cell; cpm, counts per minute; Ig, immunoglobulin; $\mathrm{mAb}$, monoclonal antibody; TcR, $\mathrm{T}$ cell receptor.

In addition, ELISA analysis demonstrated that in T cells stimulated with anti-Thy-1 mAb the production of IL-2 was significantly less compared with IL-2 production in anti-TcR $\beta$ $\mathrm{mAb}$-stimulated T cells (Fig. 4). However, the addition of $100 \mathrm{U} / \mathrm{ml}$ recombinant mouse IL-2 to anti-Thy-1 mAb-stimulated $\mathrm{T}$ cell cultures did not appear to enhance DNA synthesis (data not shown).

Thy-1-induced ZAP-70 and ERK1/2 phosphorylation is delayed compared with TcR-induced phosphorylation. The ability of anti-Thy- $1 \mathrm{mAb}$ and anti-TcR $\beta$ mAb crosslinking to induce phosphorylation of the ZAP-70 tyrosine kinase and ERK1/2 MAPK in T cells was investigated in the presence of syngeneic BMDCs. As presented in Fig. 5A, the phosphorylation of ZAP-70 at Tyr319 was increased 5 min following $T$ cell activation with anti-TcR $\beta \mathrm{mAb}$ and remained elevated relative to the $0 \mathrm{~min}$ control at all subsequent time-points; conversely, following Thy-1-induced stimulation, ZAP-70 phosphorylation was not detected until
A

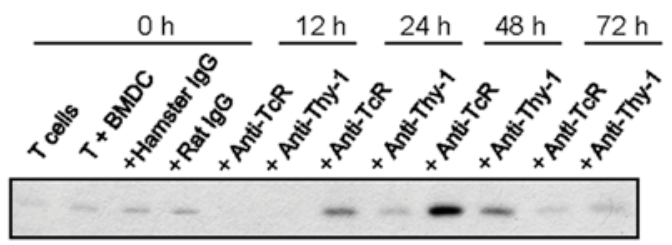

$\beta$-actin $--\ldots-\cdots$

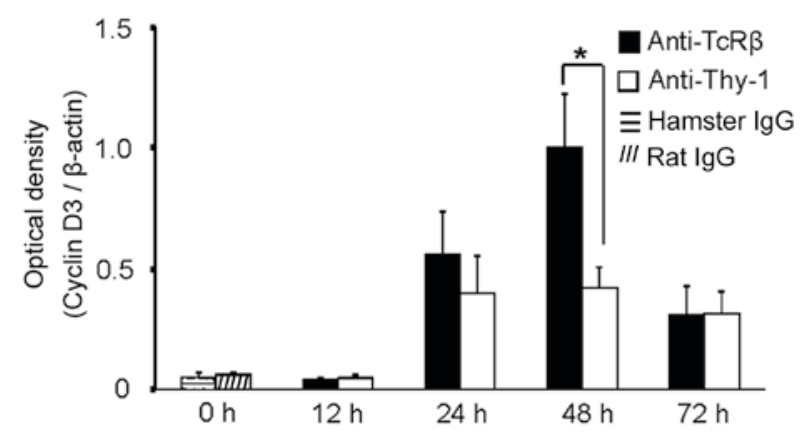

B
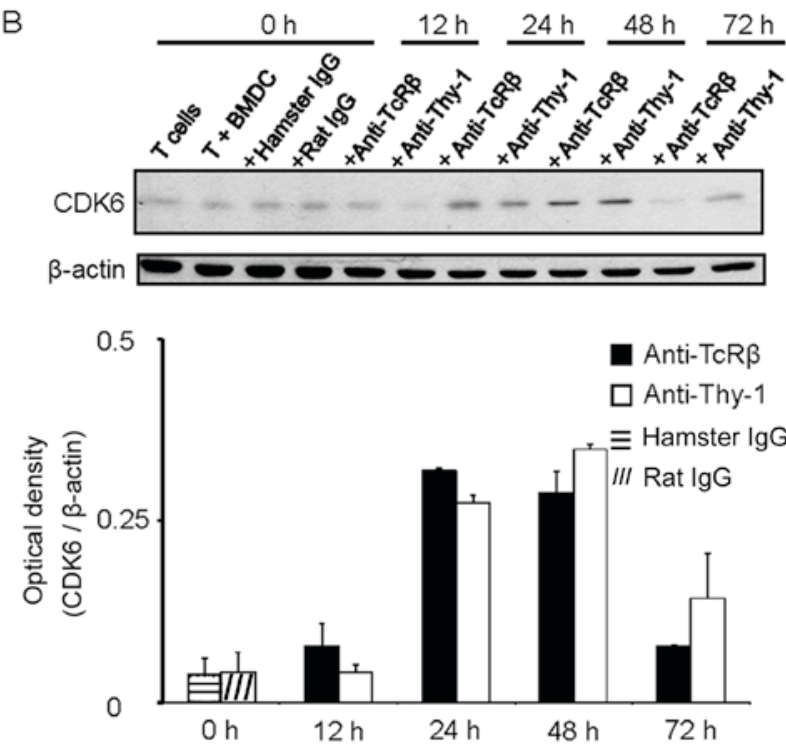

Figure 2. Effects of Thy-1 and TcR signaling on cyclin D3 and CDK6 protein expression. T cells with or without lipopolysaccharide-matured BMDCs were cultured in the presence or absence of $6 \mu \mathrm{g} / \mathrm{ml}$ anti-Thy- $1 \mathrm{mAb}$, anti-TcR $\beta$ $\mathrm{mAb}$ or an isotype control for the indicated times. Only the $0 \mathrm{~h} \mathrm{~T}$ cell group was cultured without BMDCs. Protein expression levels in cell lysates were assessed using western blot analysis. Blots were probed with $\beta$-actin as a loading control. (A) Thy-1 signaling induces lower cyclin D3 protein expression compared with TcR signaling, whereas (B) CDK6 expression is similar following Thy- 1 and TcR $\beta$ stimulations. Blots are representative of 3 independent experiments. Data are expressed as the mean optical density ratio normalized to $\beta$-actin \pm standard error of the mean of 3 independent experiments. ${ }^{*} \mathrm{P}<0.05$, as indicated. Data at the $0 \mathrm{~h}$ time-point compares $\mathrm{T}$ cells plus BMDCs treated with hamster IgG vs. rat IgG. BMDC, bone marrow-derived dendritic cell; CDK, cyclin-dependent kinase; Ig, immunoglobulin; mAb, monoclonal antibody; T, T cells; TcR, T cell receptor.

the 120 min time-point and remained elevated relative to the 0 min control at the 240 min time-point. Similarly, Fig. 5B reveals that ERK1 and ERK2 phosphorylation was not detected until 60 min following Thy-1 stimulation and remained elevated at all later time-points. By contrast, ERK1 and ERK2 phosphorylation in response to TcR crosslinking 

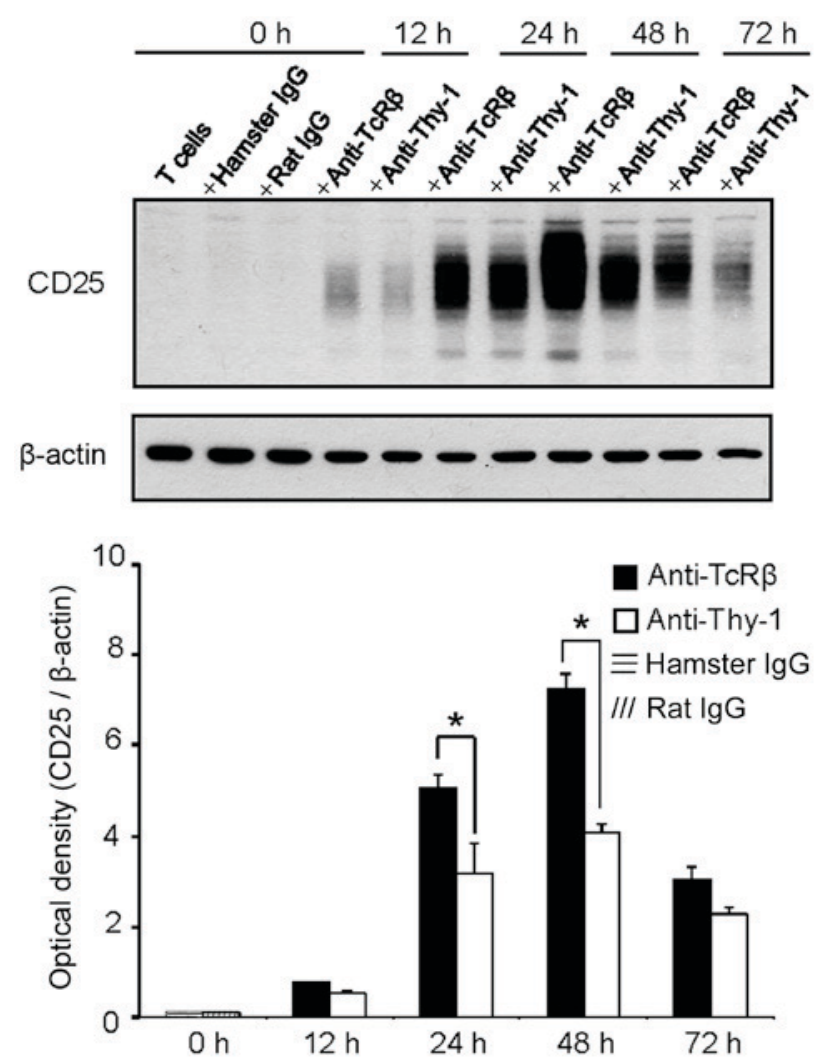

Figure 3. Thy-1 signaling is a less potent inducer of CD25 protein expression compared with TcR signaling. T cells with or without lipopolysaccharide-matured BMDCs were cultured in the presence or absence of $6 \mu \mathrm{g} / \mathrm{ml}$ anti-Thy- $1 \mathrm{mAb}$, anti-TcR $\beta \mathrm{mAb}$ or an isotype control for the indicated times. Only the $0 \mathrm{~h} \mathrm{~T}$ cell group was cultured without BMDCs. CD25 protein expression levels in cell lysates were assessed by western blot analysis. Blots were probed for $\beta$-actin as a loading control. The blot is a representative of 3 independent experiments. Data are expressed as the mean optical density ratio normalized to $\beta$-actin \pm standard error of the mean of 3 independent experiments. ${ }^{*} \mathrm{P}<0.05$, as indicated. Data at the $0 \mathrm{~h}$ time-point compares $\mathrm{T}$ cells plus BMDCs treated with hamster IgG vs. rat IgG. BMDC, bone marrow-derived dendritic cell; $\mathrm{CD}$, cluster of differentiation; Ig, immunoglobulin; $\mathrm{mAb}$, monoclonal antibody; $\mathrm{TcR}, \mathrm{T}$ cell receptor.

was increased at the $5 \mathrm{~min}$ time-point, peaked at $60 \mathrm{~min}$ and declined thereafter.

Thy-1 stimulation induces Fas ligand-mediated cytotoxicity with delayed kinetics compared with TcR stimulation. The delayed kinetics of ZAP-70 and ERK1/2 phosphorylation following Thy-1 stimulation of T cells led to the hypothesis that the acquisition of cytotoxic effector function may also be delayed in Thy-1-stimulated $\mathrm{T}$ cells. Therefore, $\mathrm{T}$ cells were initially activated with anti-Thy- 1 or anti-TcR $\beta \mathrm{mAb}$ in the presence of LPS-matured BMDCs for 4, 18 and $24 \mathrm{~h}$. The cytotoxic potential of anti-Thy-1-activated and anti-TcR $\beta$-activated $\mathrm{T}$ cells against $\mathrm{Fc}$ receptor-bearing P815 target cells was then assessed by redirected lysis using 4 and $24 \mathrm{~h}$ DNA fragmentation assays. In the $4 \mathrm{~h}$ DNA fragmentation assay, anti-TcR $\beta$ $\mathrm{mAb}$-activated T cells exhibited cytotoxicity as early as $18 \mathrm{~h}$ following initial stimulation (Fig. 6A). However, in the $24 \mathrm{~h}$ DNA fragmentation assay, anti-TcR $\beta$ mAb-activated $\mathrm{T}$ cells exhibited cytotoxicity $4 \mathrm{~h}$ following their stimulation (Fig. 6B). By contrast, $\mathrm{T}$ cells that were stimulated with anti-Thy- $1 \mathrm{mAb}$ for as long as $24 \mathrm{~h}$ failed to exhibit cytotoxicity in a $4 \mathrm{~h}$ DNA

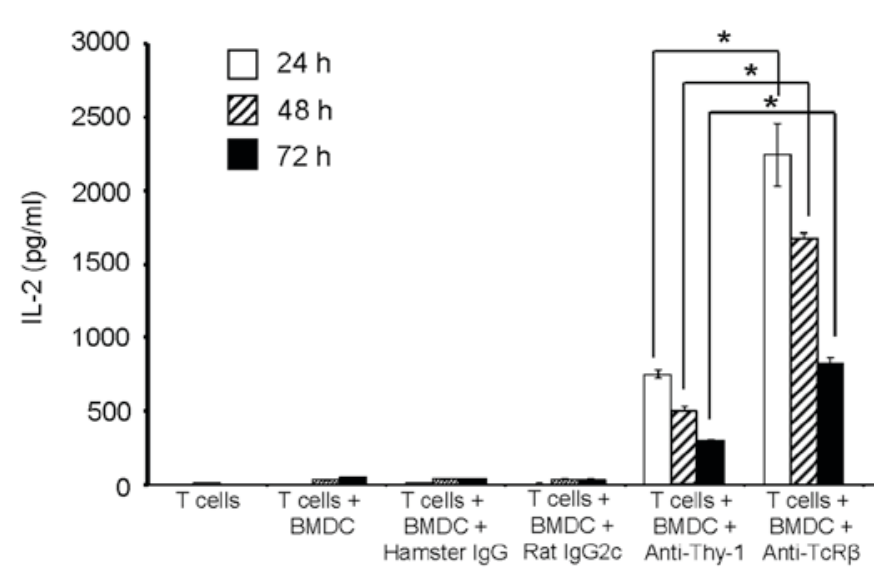

Figure 4. Thy-1 signaling is a less potent inducer of IL-2 production compared with TcR signaling. T cells with or without lipopolysaccharide-matured BMDCs were cultured in the presence or absence of $6 \mu \mathrm{g} / \mathrm{ml}$ anti-Thy-1 $\mathrm{mAb}$, anti-TcR $\beta \mathrm{mAb}$ or an isotype control for the indicated times. Cell-free culture supernatants were collected and assayed for IL-2 using a commercially available ELISA kit. Data are expressed as the mean \pm standard deviation of 3 independent experiments. ${ }^{*} \mathrm{P}<0.05$, as indicated. BMDC, bone marrow-derived dendritic cell; Ig, immunoglobulin; IL, interleukin; $\mathrm{mAb}$, monoclonal antibody; TcR, T cell receptor.

fragmentation assay (Fig. 6A); however, cytotoxic activity was observed when anti-TcR $\beta$ mAb was added to the DNA fragmentation assay, indicating that the $\mathrm{T}$ cells retained the ability to respond to TcR stimulation (Fig. 6A). Notably, Thy-1 stimulation over 18-24 $\mathrm{h}$ was able to induce cytotoxic effector function in a $24 \mathrm{~h}$ DNA fragmentation assay, however, Thy-1 stimulation for $24 \mathrm{~h}$ was required to achieve cytotoxic activity that was similar to that of TcR-stimulated T cells (Fig. 6B). The addition of anti-TcR $\beta$ mAb to the $24 \mathrm{~h}$ DNA fragmentation assay increased the cytotoxic activity of $\mathrm{T}$ cells that were activated with anti-Thy- $1 \mathrm{mAb}$ for 4 or $18 \mathrm{~h}$, however, not following $24 \mathrm{~h}$ (Fig. 6B). No significant DNA fragmentation was identified at any time-point using LPS-stimulated $\mathrm{B}$ cells as a negative control (Fig. 6A and B). In addition, cytotoxic $\mathrm{T}$ lymphocytes induced by TcR $\beta$ crosslinking demonstrated a significant reduction in effector function in $4 \mathrm{~h}$ DNA fragmentation assays performed in the presence of EGTA/ $\mathrm{MgCl}_{2}$ to chelate extracellular $\mathrm{Ca}^{2+}$ (Fig. 7A), which differentiates between $\mathrm{Ca}^{2+}$-dependent granule-mediated cytotoxicity and $\mathrm{Ca}^{2+}$-independent cytotoxicity mediated by Fas/Fas ligand interactions (27). Thus, in a $4 \mathrm{~h}$ DNA fragmentation assay, anti-TcR $\beta$-activated $\mathrm{T}$ cells rely primarily upon $\mathrm{Ca}^{2+}$-dependent granule-mediated cytotoxicity to kill target cells. Conversely, EGTA/ $\mathrm{MgCl}_{2}$ had little effect on the cytotoxic effector function of anti-TcR $\beta$-activated $\mathrm{T}$ cells in 24-h DNA fragmentation assays, indicating a major role for a $\mathrm{Ca}^{2+}$-independent cytotoxic mechanism (Fig. 7B). Anti-Thy-1-activated $\mathrm{T}$ cells did not exhibit $\mathrm{Ca}^{2+}$-dependent or -independent cytotoxic activity in the $4 \mathrm{~h}$ DNA fragmentation. In the $24 \mathrm{~h}$ DNA fragmentation assay, the cytotoxic activity of anti-Thy-1-activated $\mathrm{T}$ cells was not affected by EGTA/ $\mathrm{MgCl}_{2}$, indicating that cytotoxicity was $\mathrm{Ca}^{2+}$ independent. These findings indicated that a longer duration of Thy-1 signaling may be required for $\mathrm{T}$ cells to acquire $\mathrm{Ca}^{2+}$-independent cytotoxic effector function, which accounts for all of their cytotoxic activity. 
A

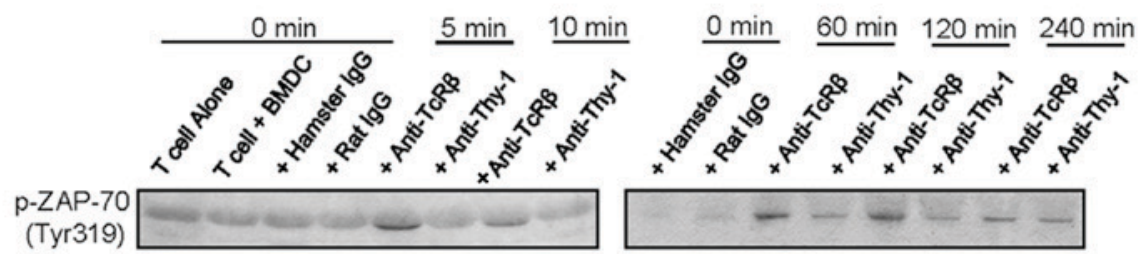

Total ZAP-70
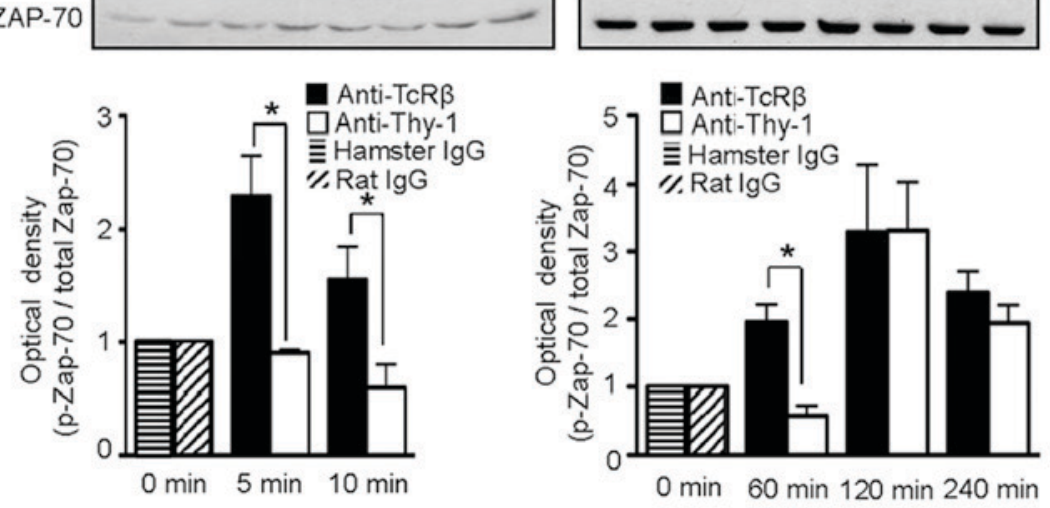

B
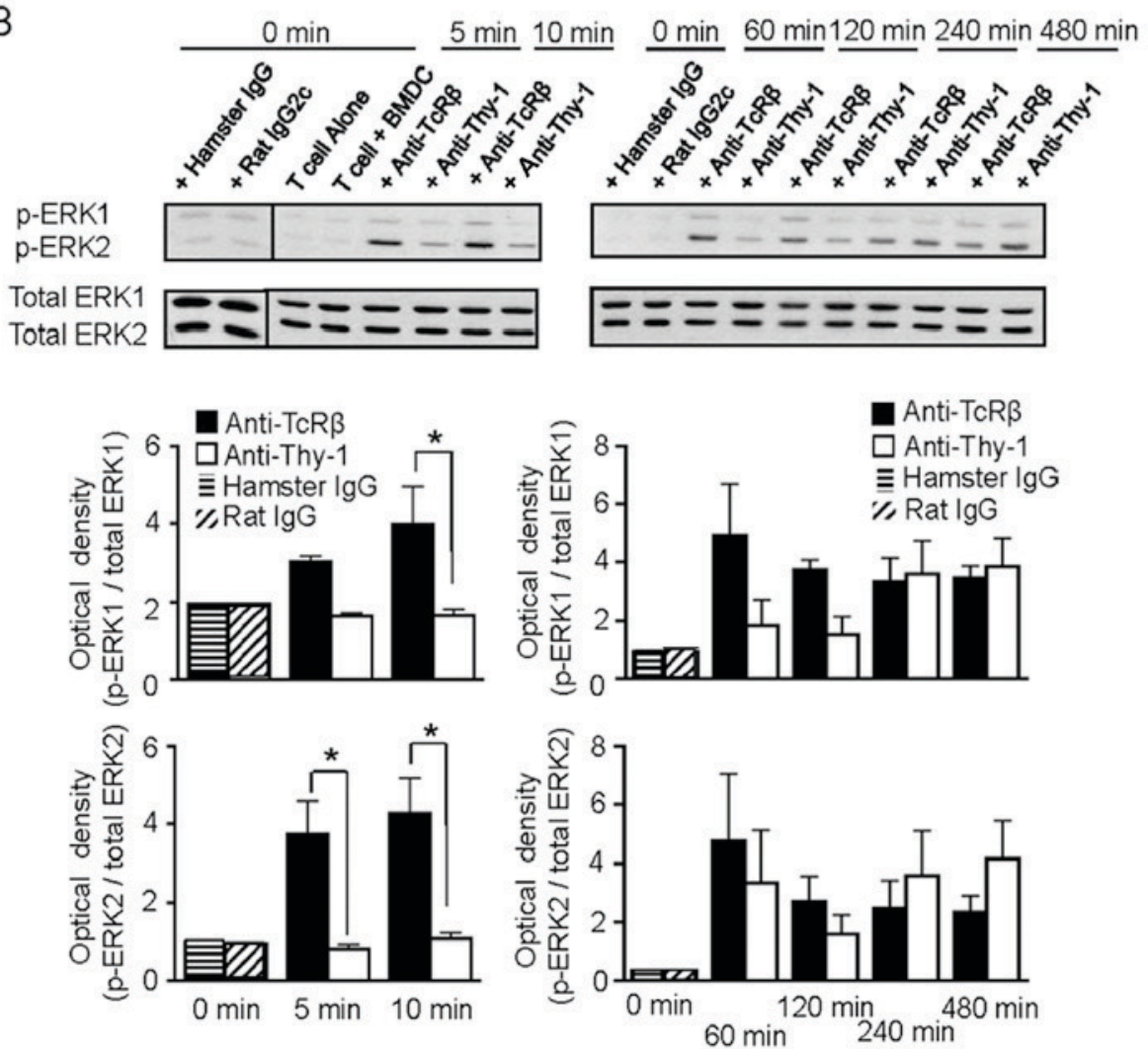

Figure 5. Thy-1 signaling induces delayed ZAP-70, ERK1 and ERK2 phosphorylation compared with TcR signaling. T cells with or without lipopolysaccharide-matured BMDCs were cultured in the presence or absence of $6 \mu \mathrm{g} / \mathrm{ml}$ anti-Thy- $1 \mathrm{mAb}$, anti-TcR $\beta$ mAb or an isotype control for the indicated times. Only the $0 \mathrm{~h}$ T cell group was cultured without BMDCs. (A) p-ZAP-70 (Tyr319) and (B) p-ERK1 and p-ERK2 protein expression levels in cell lysates were assessed using western blot analysis. Blots were then probed for (A) total ZAP-70 or (B) total ERK1 and total ERK2 as a loading control. Blots are representative of 3 independent experiments. Data are expressed as the mean optical density ratio of (A) p-ZAP-70 normalized to total ZAP-70 or (B) p-ERK1 and p-ERK2 normalized to total ERK1 and total ERK2, respectively, mean \pm standard error of the mean of 3 independent experiments. ${ }^{*} \mathrm{P}<0.05$, as indicated. Data at the 0 min time-point compares T cells plus BMDCs treated with hamster IgG vs. rat IgG. BMDC, bone marrow-derived dendritic cell; ERK, extracellular signal-regulated kinase; Ig, immunoglobulin; mAb, monoclonal antibody; p, phosphorylated; TcR, T cell receptor; ZAP, $\zeta$-chain-associated protein kinase.

\section{Discussion}

In the present study, the $\mathrm{T}$ cell-activating signal generated by crosslinking of Thy- 1 by $\mathrm{mAb}$ via $\mathrm{Fc}$ receptors on syngeneic
BMDCs and associated costimulatory signaling was revealed to be relatively weak and delayed compared with the signal generated by anti-TcR $\beta \mathrm{mAb}$-mediated stimulation under similar conditions. Therefore, at the maximal mitogenic concentration, 
A

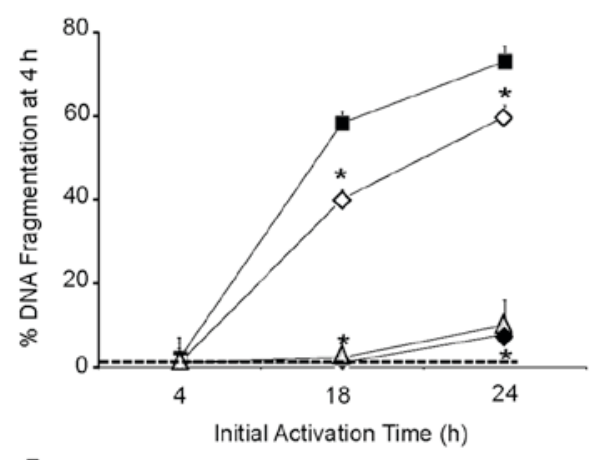

B

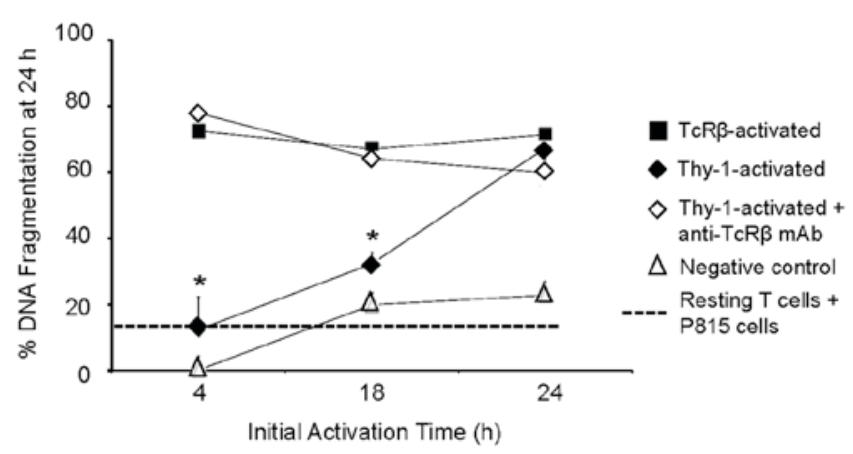

Figure 6. Cytotoxic effector function is acquired later following Thy-1 stimulation compared with TcR stimulation and induces DNA fragmentation of target cells after $24 \mathrm{~h}$. T cells with or without LPS-matured BMDCs were cultured in the presence or absence of $6 \mu \mathrm{g} / \mathrm{ml}$ anti-Thy- $1 \mathrm{mAb}$ or anti-TcR $\beta$ $\mathrm{mAb}$ for 4,18 or $24 \mathrm{~h}$. The resulting activated $\mathrm{T}$ cells were co-cultured with $\left[{ }^{3} \mathrm{H}\right]$-TdR-labeled murine P815 target cells at a 50:1 effector to target cell ratio with or without $1 \mu \mathrm{g} / \mathrm{ml}$ anti-TcR $\beta \mathrm{mAb}$ in order to allow redirected lysis to occur. LPS-activated BMDCs were combined with P815 cells at the same effector to target cell ratio as a negative control. Intact DNA from effector cell-target cell co-cultures was harvested following (A) 4 or (B) $24 \mathrm{~h}$, and quantified using liquid scintillation counting. Data are expressed as the mean \pm standard deviation of 3 independent experiments. " $\mathrm{P}<0.05$ vs. TcR $\beta$-activated $\mathrm{T}$ cells. $\left[{ }^{3} \mathrm{H}\right]$-TdR, tritiated thymidine; BMDC, bone marrow-derived dendritic cell; LPS, lipopolysaccharide; mAb, monoclonal antibody; TcR, T cell receptor.

anti-Thy-1 mAb was less potent in its ability to promote cyclin D3 expression, DNA synthesis, CD25 protein expression and IL-2 production, which are markers of T cell activation (30), compared with the anti-TcR $\beta$ mAb. It was hypothesized that a greater number of Thy-1 molecules were crosslinked by $\mathrm{mAb}$ compared with $\mathrm{TcR} \beta$, as excess mAbs were used, and it has been reported that T cells express 200,000 Thy-1 molecules/cell and only $\sim 2,000 \mathrm{TcR}$ molecules/cell $(31,32)$. This serves to underscore the relative weakness of the activation signal delivered by Thy- 1 compared with TcR, and argues that any minor differences in the affinity of each $\mathrm{mAb}$ for its target are unlikely to account for the observed effects. In addition, the expression of survivin was similar in anti-Thy-1 mAb- and anti-TcR $\beta$ mAb-stimulated $\mathrm{T}$ cells, which suggested that the activation of the signaling pathway controlling the expression of this antiapoptotic molecule was similar under both stimulation conditions. As the proliferation of activated T cells depends on the autocrine IL-2/IL-2 receptor system (29), it may be that the weaker proliferative response of T cells to Thy-1 crosslinking compared with TcR $\beta$ crosslinking was a consequence of low IL-2 synthesis and/or CD25 expression. However, insufficient
A

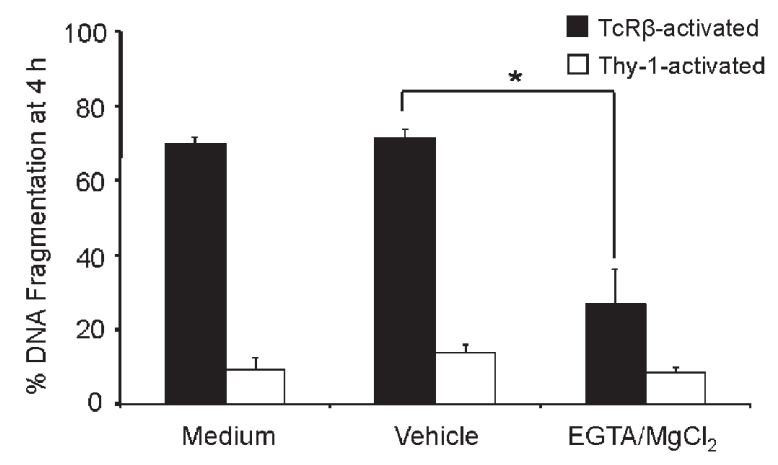

B

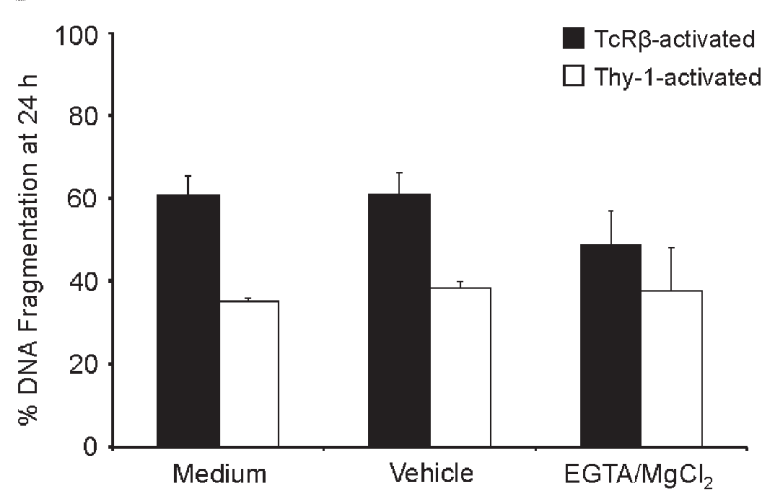

Figure 7. Thy-1 stimulation induces $\mathrm{Ca}^{2+}$-independent cytotoxicity in $\mathrm{T}$ cells. $\mathrm{T}$ cells with or without lipopolysaccharide-matured BMDCs were cultured in the presence or absence of $6 \mu \mathrm{g} / \mathrm{ml}$ anti-Thy- $1 \mathrm{mAb}$ or anti-TcR $\beta \mathrm{mAb}$ for $24 \mathrm{~h}$. The resulting activated $\mathrm{T}$ cells were combined with $\left[{ }^{3} \mathrm{H}\right]-\mathrm{TdR}$-labeled murine P815 target cells at a 50:1 effector to target cell ratio with medium, EGTA/ $\mathrm{MgCl}_{2}$ or the PBS vehicle. Intact DNA from effector cell-target cell co-cultures was harvested following (A) 4 or (B) $24 \mathrm{~h}$, and quantified using liquid scintillation counting. Data are expressed as the mean \pm standard error of the mean of 3 independent experiments. ${ }^{*} \mathrm{P}<0.05$, as indicated. $\left[{ }^{3} \mathrm{H}\right]-\mathrm{TdR}$, tritiated thymidine; BMDC, bone marrow-derived dendritic cell; $\mathrm{mAb}$, monoclonal antibody; TcR, T cell receptor.

IL-2 production was not the only reason behind the weak lymphoproliferative response, as the addition of exogenous IL-2 did not enhance DNA synthesis in Thy-1-stimulated T cells.

ZAP-70 is crucial for TcR signaling (33), and Thy-1-associated p85-90 contains a potential docking site for the Src homology 2 domain of ZAP-70 (15). The ERK1/2 signaling pathway, which is downstream of TcR, also serves an important role in TcR-mediated $\mathrm{T}$ cell activation and survival $(34,35)$, and in Thy-1-induced $\mathrm{T}$ cell proliferation and IL-2 production (11). The present study revealed that the phosphorylation of ZAP-70 and ERK1/2 was delayed in Thy-1-stimulated T cells compared with $\mathrm{T}$ cells activated with TcR $\beta$ mAb, which may have contributed to the reduced IL-2 and CD25 expression and the subsequent suppression of DNA synthesis. Thy-1 and TcR signaling pathways involve the activation of protein tyrosine kinases $(10,36)$. Phosphorylation of tyrosine residues in the immunoreceptor tyrosine-based activation motifs (ITAMs) of the TcR-associated $\zeta$ chain by Lck, and to a lesser extent by Fyn, was previously revealed to result in the recruitment and activation of ZAP-70 (33). Therefore, the phosphorylation of 
ZAP-70 in response to Thy-1 crosslinking suggested a possible prior Lck- and/or Fyn-mediated phosphorylation of $\zeta$ chain ITAMs. Thy-1 is not physically associated with the TcR (16); however, Thy-1 co-localizes with Lck and Fyn in lipid rafts that aggregate in response to Thy-1 crosslinking (37). Therefore, Thy-1 stimulation may bring Lck and Fyn molecules in close proximity with $\zeta$ chain ITAMs, which may result in the activation of downstream signaling molecules. The present study hypothesized that Thy-1 signaling may be weaker and has delayed kinetics compared with TcR signaling, owing to the poor accessibility of the $\zeta$ chain to Thy-1-aggregated Lck and Fyn.

The delayed kinetics of ZAP-70 and ERK1/2 phosphorylation following Thy-1 crosslinking led to the re-evaluation of our previous findings, which suggested that Thy-1-activated $\mathrm{T}$ cells may fail to function in $4 \mathrm{~h}$ cytotoxicity assays, even though these cells possess cytolytic granules and effector molecules (7). Granule-mediated cytotoxicity, which is dependent on extracellular $\mathrm{Ca}^{2+}$ and involves the exocytosis of granule-associated granzymes and perforin, and cytotoxicity mediated via the Fas/Fas ligand death-receptor pathway, which does not use extracellular $\mathrm{Ca}^{2+}$, are the two principal effector mechanisms of cytotoxic $\mathrm{T}$ lymphocytes (38). The results of the present study suggested that, unlike granule-mediated $\mathrm{T}$ cell cytotoxicity induced by TcR crosslinking, Thy-1 stimulation resulted in the delayed induction of $\mathrm{Ca}^{2+}$-independent cytotoxic activity. These data suggested that Fas ligand-mediated pathways, rather than cytotoxic granule proteins, may be involved in Thy-1-induced $\mathrm{T}$ cell cytotoxicity. The present findings are consistent with a previous study that used the BAK $\mathrm{CD}^{+} \mathrm{T}$ cell line, which were stimulated with immobilized anti-CD3 or anti-Thy-1 mAb in the absence of costimulation (39). Notably, weak TcR signaling was also previously reported to activate Fas ligand-mediated cytotoxicity, but not granule-dependent cytotoxicity in T cells (22). As the mobilization of preformed Fas ligand from cytotoxic granules, rather than de novo synthesis, is favored by weak TcR signaling (23), it may be hypothesized that cytolytic granules may also be the source of the Fas ligand used by Thy-1-stimulated cytotoxic T cells, which possess cytoplasmic granules and express abundant mRNA transcripts coding for Fas ligand, perforin and granzyme B (7).

The physiological ligand for $\mathrm{T}$ cell-associated Thy-1 within immune compartments has yet to be determined (1-3); however, the non-polymorphic region of Thy-1 contains an Arg-Gly-Asp-like integrin-binding motif of Arg-Leu-Asp (40). Therefore, Thy-1 expression on activated endothelial cells may interact with $\alpha_{M} \beta_{2}, \alpha_{X} \beta_{2}$, and $\alpha_{V} \beta_{3}$ integrins, as well as CD97; in addition $\alpha_{\mathrm{V}} \beta_{3}$ and Syndecan-4 are ligands for neuronal Thy-1, and Thy-1 expressed by activated fibroblasts binds $\alpha_{\mathrm{V}} \beta_{5^{-}}$and $\beta_{2}$-containing integrins (1). As the mitogenic anti-Thy-1 mAb (clone G7) used in the present study binds to the non-polymorphic region of Thy-1 (41), this mAb may interact with and crosslink a ligand-binding domain that triggers a signal similar to that induced by the physiological ligand. As Thy-1 may induce a non-specific TcR-like signal that promotes the development of Fas ligand-mediated cytotoxic effector function, it is suggested that the expression of the Thy-1 ligand in immune compartments may be strictly regulated to avoid potentially dangerous immunopathologies. However, the non-specific activation and proliferation of
T cells in response to Thy- 1 stimulation may serve a role in the clearance of intracellular pathogens that can subvert the development of antigen-specific immune responses (42). Consistent with the involvement of Thy-1 in T cell-mediated immune responses, Thy-1-deficient mice were previously reported to exhibit diminished delayed-type hypersensitivity reactions (6).

In conclusion, the present study demonstrated that mAb-mediated crosslinking of Thy-1, in the context of costimulation by BMDCs, provided mouse $\mathrm{T}$ cells with a TcR-like signal that was less potent and exhibited delayed kinetics compared with endogenous TcR signaling. In addition, Thy-1-activated $\mathrm{T}$ cells exhibited $\mathrm{Ca}^{2+}$-independent cytotoxicity in $24 \mathrm{~h}$ cytotoxicity assays, which is in accordance with previous reports that granule-mediated cytotoxicity may not be triggered by Thy-1 stimulation $(7,39)$. The findings of the present study may serve to advance our understanding of the roles of Thy-1 in mouse $\mathrm{T}$ cell function.

\section{Acknowledgements}

The present study was supported by a Discovery Grant from the Natural Sciences and Engineering Research Council (NSERC; grant no. RGPIN/46295-2011). Suzanne Furlong was the recipient of an NSERC Postgraduate Scholarship.

\section{References}

1. Herrera-Molina R, Valdivia A, Kong M, Alvarez A, Cárdenas A, Quest AF and Leyton L: Thy-1-interacting molecules and cellular signaling in cis and trans. Int Rev Cell Mol Biol 305: 163-216, 2013.

2. Killeen N: T-cell regulation: Thy-1-hiding in full view. Curr Biol 7: R774-R777, 1997.

3. Haeryfar SM and Hoskin DW: Thy-1: More than a mouse pan-T cell marker. J Immunol 173: 3581-3588, 2004.

4. Hueber AO, Bernard AM, Battari CL, Marguet D, Massol P, Foa C, Brun N, Garcia S, Stewart C, Pierres M and He HT: Thymocytes in Thy-1/- mice show augmented TCR signaling and impaired differentiation. Curr Biol 7: 705-708, 1997.

5. Conrad DM, Coombs MR, Furlong SJ, Forward NA and Hoskin DW: Induction of CD4(+)CD25(+)Foxp3(-) regulatory $\mathrm{T}$ cells by Thy-1 stimulation of CD4(+) T cells. Immunol Cell Biol 90: 248-252, 2012.

6. Beissert S, He HT, Hueber AO, Lellouch AC, Metze D, Mehling A, Luger TA, Schwarz T and Grabbe S: Impaired cutaneous immune responses in Thy-1-deficient mice. J Immunol 161: 5296-5302, 1998.

7. Haeryfar SM, Al-alwan MM, Mader JS, Rowden G, West KA and Hoskin DW: Thy-1 signaling in the context of costimulation provided by dendritic cells provides signal 1 for T cell proliferation and cytotoxic effector molecule expression, but fails to trigger delivery of the lethal hit. J Immunol 171: 69-77, 2003.

8. Leyton L, Quest AF and Bron C: Thy-1/CD3 coengagement promotes TCR signaling and enhances particularly tyrosine phosphorylation of the raft molecule LAT. Mol Immunol 36: 755-768, 1999.

9. Kroczek RA, Gunter KC, Germain RN and Shevach EM: Thy-1 functions as a signal transduction molecule in T lymphocytes and transfected B lymphocytes. Nature 322: 181-184, 1986.

10. Haeryfar SM and Hoskin DW: Selective pharmacological inhibitors reveal differences between Thy-1- and $\mathrm{T}$ cell receptor-mediated signal transduction in mouse $\mathrm{T}$ lymphocytes. Int Immunopharmacol 1: 689-698, 2001.

11. Conrad DM, Furlong SJ, Doucette CD, Boudreau RT and Hoskin DW: Role of mitogen-activated protein kinases in Thy-1-induced T-lymphocyte activation. Cell Signal 21: 1298-1307, 2009.

12. Gunter KC, Germain RN, Kroczek RA, Saito T, Yokoyama WM, Chan C, Weiss A and Shevach EM: Thy-1-mediated T-cell activation requires co-expression of CD3/Ti complex. Nature 326: 505-507, 1987. 
13. Thomas PM and Samelson LE: The glycophosphatidylinositol-anchored Thy-1 molecule interacts with the p60 ${ }^{\text {fyn }}$ protein tyrosine kinase in T cells. J Biol Chem 267: 12317-12322, 1992.

14. Bohuslav J, Cinek T and Horejsi V: Large, detergent-resistant complexes containing murine antigens Thy- 1 and Ly- 6 and protein tyrosine kinase p56 ${ }^{\text {lck }}$. Eur J Immunol 23: 825-831, 1993.

15. Durrheim GA, Garnett D, Dennehy KM and Beyers AD: Thy-1 associated pp85-90 is a potential docking site for SH2 domain-containing signal transduction molecules. Cell Biol Int 25: 33-42, 2001 .

16. Volarević S, Burns CM, Sussman JJ and Ashwell JD: Intimate association of Thy-1 and the T-cell antigen receptor with the CD45 tyrosine phosphatase. Proc Natl Acad Sci USA 87: 7085-7089, 1990.

17. Ilangumaran S, He HT and Hoessli DC: Microdomains in lymphocyte signalling: Beyond GPI-anchored proteins. Immunol Today 21: 2-7, 2000.

18. Adachi $\mathrm{S}$ and Iwata M: Duration of calcineurin and Erk signals regulates CD4/CD8 lineage commitment of thymocytes. Cell Immunol 215: 45-53, 2002.

19. Rogers PR and Croft M: Peptide dose, affinity, and time of differentiation can contribute to the Th1/Th2 cytokine balance. J Immunol 163: 1205-1213, 1999.

20. Lozza L, Rivino L, Guarda G, Jarrossay D, Rinaldi A, Bertoni F, Sallusto F, Lanzavecchia A and Geginat J: The strength of T cell stimulation determines IL-7 responsiveness, secondary expansion, and lineage commitment of primed human CD4 $4^{+} I L-7 R^{\text {hi }}$ T cells. Eur J Immunol 38: 30-39, 2008

21. Svensson M, Johansson-Lindbom B, Zapata F, Jaensson E, Austenaa LM, Blomhoff R and Agace WW: Retinoic acid receptor signaling levels and antigen dose regulate gut homing receptor expression on $\mathrm{CD}^{+} \mathrm{T}$ cells. Mucosal Immunol 1: 38-48, 2008.

22. Kessler B, Hudrisier D, Schroeter M, Tschopp J, Cerottini JC and Luescher IF: Peptide modification or blocking of CD8, resulting in weak TCR signaling, can activate CTL for Fas-but not perforin-dependent cytotoxicity or cytokine production. J Immunol 161: 6939-6946, 1998.

23. He JS, Gong DE and Ostergaard HL: Stored Fas ligand, a mediator of rapid CTL-mediated killing, has a lower threshold for response than degranulation or newly synthesized Fas ligand. J Immunol 184: 555-563, 2010.

24. Lutz MB, Kukutsch N, Ogilvie AL, Rössner S, Koch F, Romani N and Schuler G: An advanced culture method for generating large quantities of highly pure dendritic cells from mouse bone marrow. J Immunol Methods 223: 77-92, 1999.

25. Haeryfar SM, Conrad DM, Musgrave B and Hoskin DW: Antibody blockade of Thy-1 (CD90) impairs mouse cytotoxic $\mathrm{T}$ lymphocyte induction by anti-CD3 monoclonal antibody. Immunol Cell Biol 83: 352-363, 2005.

26. Matzinger P: The JAM test. A simple assay for DNA fragmentation and cell death. J Immunol Methods 145: 185-192, 1991.
27. Brahmi Z, Hommel-Berrey G, Smith F and Thomson B: NK cells recover early and mediate cytotoxicity via perforin/granzyme and Fas/FasL pathways in umbilical cord blood recipients. Hum Immunol 62: 782-790, 2001.

28. Kwon TK, Park JW, Buchholz MA and Nordin AA: The expression and characterization of cyclin-dependent kinase 6 during the activation of murine G0 T-cells. Mol Cells 12:313-320,2001.

29. Malek TR, Ashwell JD, Germain RN, Shevach EM and Miller J: The murine interleukin-2 receptor: Biochemical structure and regulation of expression. Immunol Rev 92: 81-101, 1986.

30. Baksh S and Burakoff SJ: The role of calcineurin in lymphocyte activation. Semin Immunol 12: 405-415, 2000.

31. Pont S: Thy-1: A lymphoid cell subset marker capable of delivering an activation signal to mouse T lymphocytes. Biochimie 69: 315-320, 1987.

32. Acuto O and Michel F: CD28-mediated co-stimulation: A quantitative support for TCR signalling. Nat Rev Immunol 3: 939-951, 2003.

33. Chan AC, Irving BA, Fraser JD and Weiss A: The zeta chain is associated with a tyrosine kinase and upon T-cell antigen receptor stimulation associates with ZAP-70, a 70-kDa tyrosine phosphoprotein. Proc Natl Acad Sci USA 88: 9166-9170, 1991.

34. Dong C, Davis RJ and Flavell RA: MAP kinases in the immune response. Ann Rev Immunol 20: 55-72, 2002.

35. Robertson LK, Mireau LR and Ostergaard HL: A role for phosphatidylinositol 3-kinase in TCR-stimulated ERK activation leading to paxillin phosphorylation and CTL degranulation. J Immunol 175: 8138-8145, 2005.

36. Salmond RJ, Filby A, Qureshi I, Caserta S and Zamoyska R: T-cell receptor proximal signaling via the Src-family kinases, Lck and Fyn, influences T-cell activation, differentiation, and tolerance. Immunol Rev 228: 9-22, 2009.

37. He HT and Marguet D: T-cell antigen receptor triggering and lipid rafts: A matter of space and time scales. Talking Point on the involvement of lipid rafts in T-cell activation. EMBO Rep 9: 525-530, 2008

38. Fan Z and Zhang Q: Molecular mechanisms of lymphocyte-mediated cytotoxicity. Cell Mol Immunol 2: 259-264, 2005.

39. Kojima H, Toda M and Sitkovsky MV: Comparison of Fasversus perforin-mediated pathways of cytotoxicity in TCR- and Thy-1-activated murine T cells. Int Immunol 12: 365-374, 2000.

40. Leyton L, Schneider P, Labra CV, Rüegg C, Hetz CA, Quest AF and Bron C: Thy-1 binds to integrin beta(3) on astrocytes and triggers formation of focal contact sites. Curr Biol 11: 1028-1038, 2001.

41. Gunter KC, Malek TR and Shevach EM: T cell-activating properties of an anti-Thy-1 monoclonal antibody. Possible analogy to OKT3/Leu-4. J Exp Med 159: 716-730, 1984

42. McSorley SJ: The role of non-cognate $\mathrm{T}$ cell stimulation during intracellular bacterial infection. Front Immunol 5: 319, 2014. 